\title{
Requesting "non-Ketabi” People to Take a Conclusive Oath not Conjoined with the Word "Allah" Under the Jordanian Legislation: A Comparative Study
}

\author{
Maher Jaber Aljaber \\ Assistant Professor, School of Law, Al-Balqa Applied University, PO box 19117, Al-Salt, Jordan
}

\begin{abstract}
All laws entitle people to claim for their rights. That can be done under a litigation system. That can be done through filing a lawsuit and providing a proof in accordance with the provisions of the law. Under the Jordanian legislations, there are several types of proofs; (written documents, testimony, physical proof, confession, oath and expertise).Thus, taking the oath is one of the types of proofs under the Jordanian legislations. The oath is taken for settling conflicts between the disputed parties. The Arab legislations - including the Jordanian legislations- are derived from the Islamic jurisprudence and Shariah. For instance, it's not permitted -under the Arab legislationsto request people to take a conclusive oath that is not conjoined with the word "Allah". If the oath is not conjoined with the word "Allah", the oath shall not be considered admissible nor binding. Hence, the present study aimed to shed a light on the legitimacy of requesting "non-Ketabi" people - (i.e. the ones who aren't Muslim, Christian nor Jewish)- to take a conclusive oath that's not conjoined with the word "Allah". The present study also aimed to identify whether such an oath is considered binding or not. It also aimed to identify the legal implications derived from taking such an oath. It adopts an analytical inductive approach. The researcher reviewed the opinions of several Islamic jurists.
\end{abstract}

Keywords: Conclusive Oath, Supplementary Oath. Believers in Allah, Non-Believers in Allah.

DOI: $10.7176 / \mathrm{JLPG} / 85-17$

Publication date:May $31^{\text {st }} 2019$

\section{Introduction}

The heavenly laws were enacted before enacting the status laws for protecting people's rights. The latter laws entitle people to claim for their rights under a litigation system. Under such a system, people can restore their rights. All the judicial systems seek preventing the oppressive practices. In order to ensure that such prevention is achieved, judicial systems set several procedures that plaintiffs are obliged to comply with. These procedures are identified through a litigation system. For instance, article 101/1 of the Jordanian constitution states that "The courts shall be open to all..." Article 102 of the Jordanian constitution states that "The Civil Courts in the Hashemite Kingdom of Jordan shall have jurisdiction over all persons in all matters, civil and criminal...".

Having a litigation system is considered important since early ages. For instance, Iben Ayas said that Prophet Mohammad (PBUH): "If people are given everything they claim for, they shall claim for the wealth and lives of others. Therefore, the claimant must bring a proof and the defendant may be requested to take the oath"1. Thus, one can't retrieve his right without providing a proof. The word proof refers to a thing indicating that there's a right that must be retrieved ${ }^{2}$.

Lawsuit is a mean through which the claimant claiming for a substantive right can resort to a judiciary to retrieve this right ${ }^{3}$.Lawsuit may be defined as a mean for declaring that a right must be retrieved to someone. This This proof shall be presented before a governor, arbitrator, master, or a person of an authority ${ }^{4}$. Through the lawsuit, lawsuit, the claimant of a right shall call the defendant to appear before a judicial council. In this context, the claimant refers to the one claiming for his/her right. As for the defendant, it refers to the one being accused of infringing the claimant's right ${ }^{5}$.

In order for the claimant to prove that his right has been infringed, he must follow the procedures that were set thorough the law. That is done through providing one type of proof or several ones in accordance with the provisions of the concerned law ${ }^{6}$. Under the Jordanian legislations, there are several types of proofs, which are: (written documents, testimony, physical proof, confession, oath and expertise).

The Jordanian legislator identifies such types of proofs because the claim of the claimant is considered weak. That's considered so because the defendant is assumed to be innocent. Thus, under the Jordanian legislations, if the claimant provides a weak evidence, it wouldn't be sufficient to prove his claim. As for the defendant, he is

\footnotetext{
${ }^{1}$ Al-Bayhaqi, Al-Sunan Al-Kubrah. Reviewed by Mohammad Abed Al-QaderAttah. Part No.10. First edition

${ }^{2}$ Nash'at. A letter about proof.Part No. 1. First edition. p.19

${ }^{3} \mathrm{Al}-\mathrm{Zu}$ 'bi, Al-Wajeez about the Jordanian civil procedure code. First edition. p.9/10

${ }^{4}$ Othman. The judicial system under the Islamic jurisprudence. The second edition. p.216

${ }^{5}$ Othman, op. cit. p.219

${ }^{6}$ Nash'at, op cit.
} 
assumed to be innocent. Thus, under the Jordanian legislations, if the defendant provides a weak evidence, it would be sufficient to prove his claim. Under the Jordanian legislations, the claimant must provide a strong evidence to prove his claim. The Jordanian legislator set such provisions to achieve justice in the way of dealing with the claimant and the defendant ${ }^{1}$.

\section{The Study's Methodology}

Through the present study, the researcher sheds a light on the process of requesting "non-Ketabi" people to take a conclusive oath. He also sheds a light on the admissibility of the oath taken by those people, if the oath isn't conjoined with the word "Allah" or any of his attributes. In order to meet the study's goals, the researcher reviewed the relevant opinions of jurists and legal texts. The main sources of data in the present researcher include: the Jordanian code of proof, several codes of Arab countries, and the opinions of Islamic jurists. The researcher also aimed to explore the opinions of Islamic jurists of different schools of Islamic jurisprudence. These opinions are concerned with the form of the conclusive oath and the words that must be conjoined with the oath.

\section{The Concept of (Proving) and Its Significance}

The concept of (proving) receives much attention in Islamic Sharia and status laws. That's because proving the existence of a particular matter plays a significant role in achieving stability in life. Proving things is one of the principles that the fair judiciary must adopt. Through proving things, rights and lives are protected. The proofrelated rules shall apply to all the disputed parties. The judge must comply with such rules. When the judge complies with such rules, he shall rest assured and avoids having any oppression in his judgment. That's because such rules constitute the pillars of justice. Proving the existence of a particular matter considered the first step for achieving justice. Achieving justice is considered the second step following the process of proving the existence of a particular matter. When the judge complies with the proof-related rules, the dispute shall be settled and the disputed parties shall rest assured and feel satisfied about the judgment made by a fair judicial authority. Such a judgment is not based on nepotism, favoritism, nor preferences. Proving the existence of a particular matter is considered important under Sharia hand status laws. Therefore, Shariah and status laws provide much attention to proof-related matters. They also include several provisions that aim to regulate such matters ${ }^{2}$.

During ancient times, the term (proving) wasn't developed among jurists as it is developed now. For instance, jurists during ancient times define the term (proving) as demonstrating the occurrence of something ${ }^{3}$. Jurists today define the term (proving)as the provision of proof before the judge to demonstrate that the alleged claim is correct ${ }^{4}$. Other jurists today define the term (proving) as the provision of proof by the claimant to prove that his alleged claim is correct and the defendant's claim isn't so ${ }^{5}$.Other jurists today define the term (proving) as establishing proof before the judicial authorities through using the methods determined in Shariah to claim for a right or prove the occurrence of an event. Under Shariah, there are effects derived from establishing a proof $f^{6}$. When analyzing the latter definition through adopting an inductive approach, it can noticed that the expression (establishing a proof) stands for the term (proving). The latter expression involves every proof submitted before the judicial council or others. That applies whether the proof is submitted by one of the disputed parties or another. However, the expression (before the judge) indicates that the submission of the proof is restricted to the submission to the judicial council. It also indicates that the proof that is not submitted before the judge shall not be considered admissible. The proof must be submitted to the judge to meet the goals sought from establishing proof; i.e. retrieving a right infringed by the defendant. This is the main goal sought from filing a lawsuit and expressing an alleged claim.

Arab legislators -including the Jordanian legislator- are influenced by the Hanafi school of Islamic jurisprudence. For instance, the provisions of the Jordanian civil law are derived from the Civil Code of the Ottoman Empire. The latter code was set based on the Hanafi school of Islamic jurisprudence. However, the Jordanian legislator didn't provide a definition for (proving) explicitly. Jurists define (proving) as establishing a proof before the judiciary through the methods identified by the law in the aim of proving the existence of a legal matter. That shall lead to having legal effects ${ }^{7}$.

In the light of the aforementioned, the researcher proposes the following questions: Are the rules of proof set by the legislator procedural or substantive rules? What are the implications derived from making such a

\footnotetext{
${ }^{1}$ Othman. The judicial system under the Islamic jurisprudence. The second edition. p.219

Al-Kilany. The rules of proof and the execution-related provisions p. 130

${ }^{2}$ Al-Rjoub. Contradiction and Weighting in the means of proof. A comparative legal jurisprudential study. p.16

${ }^{3}$ Al-Jarjani. The Definitions. p.4

${ }^{4}$ The Castle of je. Al-Moyasarah Encyclopedia of jurisprudence.p.7

5 Ibrahim and Ibrahim. The legitimate means of proof under Shariah with identifying the differences between the schools of Islamic jurisprudence and the types of proofs and achieving a balance between them. The fourth edition. p. 31

${ }^{6}$ Al-Rjoub. op cit. p.14

Al-Zuhaily, Means of proof under Shariah in relation to civil paper works and personal status. p.23

${ }^{7}$ Kala'ji. Dictionary of the language of jurists. p.20
} 
classification? The rules of proof may be procedural or substantive rules ${ }^{1}$. They shall be considered procedural if they are related to the rules that deal with the procedures of submitting the proof to the judiciary. Such rules may include the ones related to time, and duration. These rules are part of the public order. They're set to achieve justice. They're connected with the litigation system. Thus, the judges and the disputed parties can't decide mutually to change or violate the rules of proof or refrain from applying these rules. On the other hand, the rules of proof may be substantive rules if they are related to means of proof or the strength of the proof in proving the existence of a particular matter. In this regard, jurists believe that some of these matters are related to the public order, such as: the judge's right to request people to take the oath. However, the jurists believe that some of these matters are related to the public order, such as: the case mentioned in article 28 of the Jordanian code of proof. The latter article permits making a testimony to prove the things that can be proved in writing ${ }^{2}$.

Under the Jordanian legislation, the oath is a mean for proving a matter. However, the English law doesn't recognize the oath as mean of proof ${ }^{3}$ which the disputed parties can use before the judge to settle a dispute. Thus, the oath is a mean for proving a matter. Taking the oath is governed by the substantive rules related to proof. These rules are related to the public order.

The present study sheds a light on the form of the oath. Article 66 of the Jordanian code of proof states" "Taking the oath is represented in saying (I swear by Allah). Then, the oath taker must say the form determined by the court". In this regard, the researcher aimed to know whether a person can take the oath without being conjoined with the word "Allah" or not. It's necessary to explore that because the ones who believes in Allah are the ones who are either Muslim, Christian, or Jewish. Thus, there are people who don't believe in the existence of Allah. Thus, what's the form of the oath that those people should be requested to take? If a person takes an oath not conjoined with the word "Allah" before the Jordanian judge, is it admissible? In case the judge requested a non-Ketabi person to take an oath that is conjoined with the word "Allah", is the judge be violating the public order of the country? In such a case, is the judge violating the provisions of the Jordanian constitution? These things shall be addressed through the present study.

\section{Definition, and Types of (Oath) and the Provisions That Govern Requesting It}

In order to answer the questions proposed in the first part, the researcher shall define the term (oath). The present part consists from the researcher shall shed a light on oath under the Islamic jurisprudence (The first section), and the Arab laws including the Jordanian law (the second section).

\subsection{Definition, and Types of (Oath)}

Many laws didn't provide a definition for the term (oath) because jurists provided a definition for it. However, such laws enacted provisions that govern issued related to (oath). The oath can be defined as (swearing by Allah that one is honest in what he's claiming with recognizing the holiness of Allah and fearing his punishment) ${ }^{4}$. The oath is a strong pledge through which one intends to do something or refrain from doing something ${ }^{5}$. In general, an (oath) refers to swearing by Allah that one is honest about the information he's delivering. It's considered a religious and civil act jointly. Dr. Al-Sanhuri suggests that an oath is a statement through which one swears by Allah that he's honest about what he's saying or doing with fearing Allah's punishment in case he is lied. The oath is used a mean of proof to enable the claimant to provide a proof in case he's not capable to provide a proof. In the latter case, the judiciary shall allow the claimant to ask the defendant to take the oath and rely on his honesty ${ }^{6}$. In order for the oath to be concluded, there are five conditions that must be met. These conditions are: maturity, sound mind, swearing by Allah, free of compulsion and intention?

The oath serves as a legal method that aims at achieving justice in order to do a paper work ${ }^{8}$.It's considered significant because it's a non-conventional mean of proof. It's adopted by status laws to settle a dispute. A conclusive oath may be requested by the claimant who can't provide a proof. In such a case, the claimant shall rely on the conscience and honesty of the defendant. However, a judge may request one of the disputed parties to take a supplementary oath in order to complement the shortcomings of the proof ${ }^{9}$. In this context, the oath refers to a judicial oath rather than a non-judicial oath. The judicial oath is the one taken before a judiciary, whereas the

\footnotetext{
${ }^{1}$ Al-Kilany. op. cit. p.31

${ }^{2}$ Abed Al-Maeed. Illustration of the code of proof

${ }^{3}$ Ibrahim, Proof In Islamic Law With Special Reference to The Sudan, page 81

${ }^{4}$ Al-Kilany. op. cit. p. 130

${ }^{5}$ Shandi, The provisions of exceptional cases in relation to the oath under Shariah (A comparative jurisprudential study).p.112

${ }^{6}$ Al-Sanhury. Al-Waseet for Illustration of the civil code: An overview about the theory of commitment-proving- the implications of commitment, p.156

${ }^{7} \mathrm{Abu}$ Ahmad. Valuable fruits found in the provisions of the oath. A study published online on the following website: http://saaid.net/bahth/search/15.html

${ }^{8}$ Al-U'budy, Illustration of the civil code of proof. $1^{\text {st }}$ edition. p.297

${ }^{9}$ Al-Sanhury. op. cit.
} 
non-judicial oath is the one that is not taken before a judiciary ${ }^{1}$. The legislator enacted provisions that govern the issues related to judicial oath. As for the non-judicial oath, it is governed by the general rules of proof. Taking the non-judicial oath is considered a physical act that can be proved through any mean of proof ${ }^{2}$.

The Jordanian legislator enacted provisions that govern issues related to oath through enacting the Jordanian code of proof No. (30) of 1952 and its adjustments. The latter legislator classified the oath into two types; conclusive and supplementary oaths. Article 53 of the Jordanian code of proof states: (the conclusive oath is an oath that may be requested by a claimant in order to settle the dispute. When a claimant isn't capable to submit a proof, he shall rely on the conscience of his adversary to prove his claim. In case the adversary took the oath, the claimant shall lose the lawsuit. The one requesting the oath shall win the lawsuit, if the adversary refrained from taking the oath. The one requesting the oath shall win the lawsuit if he took the oath because his adversary rejected taking the oath and requested him to take it) ${ }^{3}$. Thus, this section sheds a light on the conclusive oath under laws and shariah. Then, the researcher shall shed a light on the supplementary oath.

4.1.1 The Conclusive Oath

The conclusive oath is the oath requested by a lawsuit party to be taken by his adversary when he lacks proof in order to settle the dispute. Through it, the lawsuit party shall rely on the conscience of his adversary. The oath is a method established by the law for achieving justice. The legislator entitles a lawsuit party to request his adversary to take an oath when he can't provide a proof to prove his claim ${ }^{4}$. Through it, the lawsuit party relies on the conscience of his adversary or religious belief. That is because the adversary shall swear by Allah who knows the things that one conceals. Allah knows whether the person taking the oath is honest or lying. Allah promised that the one who lies in his oath shall be tortured in the afterlife. Under Shariah, the one who lies in his oath shall be punished in life if there's a proof indicating that he lies.

The conclusive oath is significant because it enables the judge to settle the dispute. The court's judgment that's based on the conclusive oath is a final judgment that one can't file an appeal against. If one requests his adversary to take an oath, it means that he waived his right to submit any proof. That's confirmed by the judgments issued by the Jordanian Court of Cassation ${ }^{5}$ and the Egyptian Court of Cassation ${ }^{6}$ in several lawsuits. However, in order for the conclusive oath to have a legal effect, it must be requested under the provisions of the law ${ }^{7}$. Thus, an oath must be requested under the provisions of the law. If the adversary took the oath, the requester of the oath shall waive his right to submit any proof. The oath requester can't retract his request. That's confirmed by the Jordanian Court of Cassation through its judgment No. 825/2004 that was issued on 2/7/2004. The latter judgment states: "requesting the adversary to take an oath doesn't mean that the requester has waived his right to submit any other proof. However, the oath requester can retract his request before his adversary takes the oath. Such retraction shall make everything goes back to the way it was before the adversary accepts taking it. Thus, no legal impact shall result from requesting the oath. The oath is personal. Thus, the acceptance which has a legal effect is the one made by the adversary himself-rather than his representative- after understanding the oath form determined by the court".

The conclusive oath is a significant oath because no appeal can be filed against the judgment that is made based on this oath. Such a judgment is considered final and shall settle the dispute. That shall apply provided that the methods of requesting one to take oath are in conformity with the provisions of the law. The Egyptian Court of Cassation confirmed that through its judgment that was issued on 27/5/2008. Under the latter judgment, the judgment issued based on the conclusive oath has a legal effect and shall settle the case. No appeal can be filed against such a judgment through using any method of the methods of appeal. That shall apply provided the appeal isn't related to the oath admissibility, lawsuit itself, or the void procedures of oath request or taking the oath. In

\footnotetext{
Al-Sa'di. Al-Wadeh for the illustration of the civil code - Proving in the civil and commercial matters Abu Al-Wafa. The rules of proof in the civil and commercial matters.

Al-U'budy. op cit. p.298

${ }^{2}$ Al-Sanhury. op cit.

${ }^{3}$ Al-Sanhury. op cit

${ }^{4}$ Al-Kilany. op cit. p.130

${ }^{5}$ The Court of Cassation issued a judgment on 12/10/2008 which holds No. $(590 / 2008)$. The latter judgment states: (If the defendant requested the representative of the claimant company to take a conclusive oath, it means that the defendant has waived his right to request any of the documents that he requested the claimant to submit as a proof).

The Court of Cassation issued a judgment on 13/8/2008 which holds No. (3493 / 2007). The latter judgment states: (If the claimant requested the defendant to take a conclusive oath and determined the oath form, the claimant shall waive his right to submit any proof".

${ }^{6}$ The Egyptian Court of Cassation issued a judgment on 17/5/1992 which holds No. 2378/55. This judgment states: "In a lawsuit presented before Al-Mansoura Court of first instance, the claimant requested the defendant to take an oath. It was requested to identify whether the defendant has paid the rent of the property he has rented for the period from xxx to xx. The defendant took the oath through which he claimed that he has paid the concerned rent. Therefore, the court decided to drop the lawsuit. That's because the notice of payment includes payments that have been already paid. The claimant filed an appeal against this judgment before the Court of Appeals. The latter court states that no appeal can be filed against this judgment according to article 117 of the code of proof. That's because the latter article states that no appeal can be filed against the judgment issued based on a conclusive oath. That's' because such a judgment is considered a final judgment that settle the dispute"

${ }^{7}$ Qasem. The code of proof in the civil and commercial matters. p, 7
} 
case the appeal is not related to any of those matters, one shall be allowed to file the appeal ${ }^{1}$.

4.1.2 The Supplementary Oath

The supplementary oath is different from the conclusive oath. Unlike the conclusive oath, the supplementary oath is requested by the judge on his own without filing a request by any of the disputed parties. The judge requests a lawsuit party to take the supplementary oath to avoid feeling suspicious about the submitted proof. Thus, the supplementary oath is taken to make the judge feel assured about the judgment he's going to make ${ }^{2}$. However, the court isn't permitted to request a lawsuit party to take the supplementary oath if there isn't any submitted proof. That was confirmed by the Jordanian Court of Cassation through its judgment that holds No. 2016/1253.

The supplementary oath is different from the conclusive oath. For instance, the supplementary oath doesn't settle the dispute. The supplementary oath's procedures are taken by the judge as part of the investigation process in the aim of identifying the truth and complementing the missing proof. Thus, the judge may issue his judgment based on the supplementary oath that has been made or based on other proofs that appear before or after making the oath. Thus, the judge is not obliged to take the oath into consideration when issuing the judgment. The supplementary oath is requested by the judge. Thus, the requested party can't refuse taking the oath and request his adversary to take $\mathrm{it}^{4}$.

Through the aforementioned argument, the researcher sheds a light on the significance of oath- especially the conclusive oath- in settling a dispute. He sheds a light on the impact of the oath on lawsuit parties and reliance on the adversary's conscience and religious beliefs when requesting him to take the oath. Through the argument below, the researcher sheds a light on the form of the oath the lawsuit party is requested to take.

\subsection{The Provisions that Govern the Request of the Conclusive Oath Under the Laws and Shariah}

The claimant is entitled to request his adversary to take the conclusive oath. However, the court isn't entitled to request a lawsuit party to take the conclusive oath. Article 54 of the Jordanian code of proof states"No one is entitled to request a lawsuit party to take the oath unless the adversary requested so and the court issued a decision requiring that". The adherents of Hanafi school of Islamic jurisprudence adopted the same belief of Al-Qaduri. For instance, according to a book written by Hanafi adherents which is titled; (Explanation of Fath Al-Qadeer with its supplement: Explanation of the fruits of thoughts, the priority of care over Guidance and Sa'adi Jalbi's thoughts in this regard), "If the claimant submitted a proof to the judge, the judge shall base his judgment on. If the claimant couldn't bring a proof and wants to request the defendant to take the oath, the claimant can ask the judge to make the defendant take an oath ${ }^{567}$ ",

The conclusive oath can't be requested unless the claimant couldn't provide a proof. This is the most important rule that govern the request of taking the conclusive oath. For instance, article 53 of the adjusted Jordanian code of proof No. 16 of 2005 states: "1.The conclusive oath is the oath requested by a claimant to be taken by his adversary to settle the dispute. 2.The court is entitled -at its own- to inform a lawsuit party that he has the right to request his adversary to take the oath if he can't prove his claim or deny the defendant's claim". Unlike the legislations of Arab countries, the Jordanian legislator states explicitly that the conclusive oath can't be taken unless the claimant couldn't prove his claim ${ }^{8}$

\footnotetext{
${ }^{1}$ The Egyptian Court of Cassation. Appeal No. 12453 of 1977/ session No. 27-5-2008. p.619

${ }^{2}$ Al-Kilany. op cit. p. 138

${ }^{3}$ The same was stated by the Egyptian Court of Cassation through its judgment which hold No. 8179 of 1964 . The latter judgment was issued on $27 / 11 / 2004$ and states that requesting a lawsuit party to take the supplementary oath requires having a submitted proof that makes the claimant believable. In case the proof isn't sufficient, the judge can allow the claimant to request the defendant to take the conclusive oath ${ }^{4} \mathrm{Ibn}$ Saleh, The authority of the civil judge in assessing proofs: A study under the civil law and the civil and administrative procedures law. p.74

${ }^{5}$ The ones adopting Al-Maleki school of Islamic jurisprudence believe the claimant is entitled to request the defendant to take the oath. The judge isn't entitled to request the defendant to take the oath, unless the claimant requested so. If the judge requested the defendant to take an oath without having the claimant's request, the oath won't have a legal effect. In such a case, the claimant can request the defendant to take the oath again.

${ }^{6}$ That was confirmed by the ones adopting Al-Shafi' school of Islamic jurisprudence. For instance, Al-Muhathab (52) states: "If the claimant doesn't have a proof and the lawsuit isn't about a murder offense, the claimant is entitled to request the defendant to take the oath. The judge isn't entitled to request the defendant to take the oath, unless the claimant requested the judge to do so. That's because this is the right of the claimant only. Therefore, no one can enjoy this right without having the claimant's approval. If the defendant took the oath based on the judge's request without having the claimant's request, the oath won't have any legal effect. That's because the oath is taken before its due time. The claimant is entitled to request the defendant to re-take the oath. That's because the first oath doesn't have a legal effect. If the claimant acquitted the defendant from taking the oath, it means that the claimant waived his right to request the defendant to take the oath in this lawsuit. In such a case, the claimant is entitled to file an appeal because he didn't drop the lawsuit through waiving this right. If the claimant filed an appeal and the defendant denied the claimant's claim, the claimant is entitled to request the defendant to take an oath. That is because this case is different from the case at which the claimant acquitted the defendant from taking the oath"

${ }^{7}$ Article 53 of the Jordanian code of proof states: "the court is entitled -at its own-to inform a lawsuit party that he has the right to request his adversary to take the oath if he can't prove his claim or deny the defendant's claim"

${ }^{8}$ Article No. 112 of the Syrian code of proof No. 359 of 1947

Article No. 114 of the adjusted code No. 18 of 1999 for the Egyptian code of proof in civil and commercial matters No. 25 of 1968.

Article 57 of the Emirati code of proof in civil and commercial matters No.10 of 1992
} 
Under the Islamic jurisprudence, the four schools of Islamic jurisprudence address this issue through the writings of Islamic jurists. The Sunni adherents believe that the oath can't be requested, unless the claimant can't provide a proof ${ }^{1}$. The adherents of Hanafi and Al-Maleki schools suggest that one may request his adversary to take the oath when his adversary denies the claimant's claim and couldn't submit a proof. The adherents of Hanafi school believe so because Prophet Mohammad (PBUH) asked a claimant: (do you have a proof? The claimant said: No. The Prophet said: You are entitled to ask your adversary to take the oath to prove truth) ${ }^{2}$. It can be noticed that the Prophet mentioned the oath after he realized that the claimant couldn't bring any proof. That's because the oath is used to prove that a specific claim is incorrect. In the latter story, the defendant denied the claim that he borrowed money from the claimant ${ }^{3}$. In case the defendant confirmed that the claim is correct, there shall be no need to make him take the oath. That's because he can't be accused of claiming something against himself.

The adherents of Al-Shafi and Al-Hanbali schools adopted the same approach. For instance, they suggest that the defendant may be requested to take the oath when he denies the claimant's claim and the claimant isn't capable to provide a proof. The adherents of Al-Shafi believe so because Prophet Mohammad (PBUH) said: "If people are given everything they claim for, they shall claim for the wealth and lives of others. Therefore, the claimant must bring a proof and the defendant may be requested to take the oath ${ }^{4}$ ". Thus, if the claimant couldn't provide a proof, he may request the defendant to take the oath. That means that priority is given for the proof over the oath to prove that the claim is correct. In case the proof is present, the claimant may not request the defendant to take the oath. The jurists base their belief in this regard on a story narrated about Omar ben Al-Khatab. Omar accepted the proof after the defendant took the oath and denied the claimant's claim. Omar said that he prefers having a valid proof over an oath. Therefore, there isn't any difference between submitting the proof before or after taking the oath, or before or after issuing the judgment. The same approach was adopted by the Jordanian legislator. For instance, the Jordanian legislator entitled the damaged party- i.e. the one who requested his adversary to take the oath-to resort to judiciary to claim for a compensation in a case he proved that his adversary's oath is false. That shall apply provided that the oath is proved to be false through a penal judgment. Article 61 of the Jordanian penal code states: " 2 .If the oath is proved to be false through a penal judgment; the damaged party is entitled to claim for a compensation." Through the aforementioned argument, the researcher proved that the conclusive oath plays a significant role in settling the dispute. The claimant is the only one entitled to request his adversary to take the oath. Through the argument below, the researcher sheds a light on the form of the oath.

\section{The Conditions of Requesting the Adversary to Take the Oath and the Form of the Oath:}

The oath - especially the conclusive oath- plays a significant role in settling the dispute and the litigation process. Therefore, the legislator has to enact legislations that govern the oath-related issue. There are laws that consider the oath as a mean of proof and there are laws that don't recognize the oath as a mean of proof, such as the English law. In the English law, taking the oath doesn't significantly affect the process of settling the dispute. The Arab legislations - including the Jordanian legislations- recognize the oath as a mean of proof. That is because these legislations are derived from the Islamic jurisprudence and Shariah. In accordance with Shariah, the Arab legislations provided an oath form which the judge and the disputed parties must adhere to. Therefore, the argument below sheds a light on the impact of the oath form on the admissibility of the judgment and how binding the judgment is for the disputed parties. The present part is divided into two sections. The first section sheds a light on the conditions of requesting the adversary to take the oath and the oath form under the Arab legislations including the Jordanian legislations. The second section sheds a light on the oath form under the Islamic jurisprudence.

\subsection{The Conditions of Requesting the Adversary to Take the Oath Under the Arab legislations - Including the Jordanian Legislations.}

The conclusive oath may be requested only by the claimant to be taken by his adversary ${ }^{5}$. Thus, the court is entitled -at its own- to inform the claimant that he has the right to request his adversary to take the oath if he can't prove his claim. As a general rule ${ }^{6}$,the court isn't entitled to act on behalf of the claimant nor request the defendant to

Ibn Dawood. About the oath and its associated issues. A study published online on the following website: http://www.cojss.com/vb/showthread.php?14720-\%D8\%B9\%D9\%86-\%D8\%A7\%D9\%84\%D9\%8A\%D9\%85\%D9\%8A\%D9\%86-\%D9\%88 \%D8\%A7\%D8\%AD\%D9\%88\%D8\%A7\%D9\%84\%D9\%87\%D8\%A7\&p=70015\&viewfull=1\#post70015

2 ibid.

${ }^{3}$ ibid

${ }^{4}$ ibid

${ }^{5}$ Article $53 / 1$ of the Jordanian code of proof

${ }^{6}$ Article 54/2 states that the court can request a lawsuit party to take the oath in any of those cases: A-If someone proved that he has an inheritance right, the court is entitled to request him to take the oath to prove that he didn't' take his right from the deceased on his own nor through assigning others nor acquitted the deceased from this right. His oath must indicate that he didn't transfer this right to others nor collected his debt from others. His oath must indicate that the deceased didn't mortgage anything in exchange for this right. B-If someone is entitled to a financial asset and his claim is proved, the court shall request him to take the oath to prove that he didn't sell this asset nor stopped being an owner for it in any form. C-If the purchaser wants to return the purchased item due to a defect, the court shall request the purchaser 
take the oath on its own. The court isn't entitled -at its own- to inform the claimant at the beginning of the law suit that he has right to request his adversary to take the conclusive oath. If the court did so, an appeal may be filed against its judgment, provided that the claimant has other proofs. That is because the court in such a case has violated the law. For instance, according to the law, the court is entitled to inform the claimant that he's entitled to request his adversary to take the oath only if he can't submit a proof proving his claim. In such a case, the oath requester shall rely on his adversary's conscience and religious beliefs ${ }^{12}$

In order for the claimant to enjoy the right of requesting his adversary to take the conclusive oath, he must be competent to act based on the right that the oath aims to retrieve. He must be so at the time of requesting the adversary to take the oath. Being a competent means that being able to take the oath or refuse taking it with requesting the adversary to take it. Thus, a child can't request the defendant to take the conclusive oath because he can't take the oath nor refuse taking it with requesting the claimant to take it. However, the guardian of the child can request - on behalf of the child- his adversary to take the conclusive oath, provided that the child is still enjoying the right that the requested oath is related to ${ }^{3}$.

Requesting the adversary to take the conclusive oath after the court informed the oath requester that he's entitled to make such request is critical. That's because no appeal can be filed against the judgment that's based on the conclusive oath. Such a judgment is considered a final one and shall settle the dispute. That was confirmed by the Egyptian Court of Cassation ${ }^{4}$. The judgment made by the latter court states: (If the one requested to take the oath took it, the information implied by the oath form shall serve as a proof that the judge must approve. In such a case, the oath is considered final and no appeal can be filed against the judgment that the conclusive oath is based upon. Regarding the claimant who requested his adversary to take the oath, he can't claim -after taking the oath- that the judgment that the oath is based upon is void through to claiming the defendant's oath is false. The claimant who requested his adversary to take the oath isn't entitled to file another lawsuit claiming for the same right through submitting new proofs. That shall apply, provided that the procedures of requesting and taking the oath are admissible and in accordance with the law).

Based on the aforementioned argument, the lawsuit party who requested his adversary to take the conclusive oath can't file a new lawsuit that concerns the same issue. That's because the judgment that is issued based on the oath is considered final and fixed. However, the oath requester can file an appeal claiming that the procedures of requesting the oath or the procedures of taking it are void because they aren't in conformity with law. Such procedures involve the procedures that concern the oath form. There isn't any specific oath form nor specific definition for the oath that all the Arab laws are mentioned in the present study agrees upon ${ }^{5}$. It should be noted that an appeal can be filed against a judgment with claiming that the form of the oath that court determined isn't in conformity with the law. The argument below sheds a light on this matter.

\subsection{The Form of the Oath Under the Islamic Jurisprudence}

This section sheds a light on the way in which the adherents of each school of Islamic jurisprudence view oath as a mean for settling dispute. It identifies the accepted form of the oath that the adherents of all schools must agree upon.

The adherents of Hanafi claim that the oath must be conjoined with the word "Allah". That is because Prophet Mohammad (PBUH) states "The one who wants to take an oath must swear by "Allah", otherwise he must refrain from taking the oath". The adherents of Hanafi believe so because Prophet Mohammad (PBUH) states: "The one who swears by any being other than the Allah shall be considered a polytheistic". The oath must be conjoined by the word Allah and shall not be considered admissible if it conjoined by anyone other than Allah. One can emphasize the oath through saying: "There is no God other than Allah who knows the seen and the unseen and the things that occur in secret and in public. He's the Most Gracious, the Most Merciful. I swear by Allah that I don't owe $\mathrm{xx}$ the amount of money he's claiming".

If the one taking the oath is Christian, or Jewish. He may take the oath through saying: "I swear by Allah who sent down the Bible or Torah to Mousa (PBUH) or Christ (PBUH)". For instance, Prophet Mohammad (PBUH)said to Ibn Surya "I request you to inform me about the punishment of adultery with swearing by Allah who sent down Torah to Mousa". Some Imam suggest that Christians, or Jewish can't be requested to swear by

to take an oath. The oath indicates that he isn't satisfied with the item due to the implicit or explicit defect. D-If the person requesting the right of preemption proved his claim, the court shall request him to take the oath. This oath shall indicate that he didn't waive his right through any mean.

${ }^{1}$ Article 53/2 of the Jordanian code of proof states:'2-The court is entitled -at its own- to inform a lawsuit party that he has the right to request his adversary to take the oath if he can't prove his claim or deny the defendant's claim".

${ }^{2}$ A study published online by the legal studies and researcher center on Facebook on:

https://m.facebook.com/center.research.legal/posts/632041256812090

${ }^{3}$ Al-Sanhuri, op cit.

${ }^{4}$ Appeal No. 17/5/1992

Appeal No. 2378/55 K

${ }^{5}$ Ibrahim op cit. page 404, 
anyone other than Allah because they claim that such an act shall glorify the beliefs of other religions ${ }^{1}$. As for Majus, he shall be requested to swear by Allah who created fire. Thus, it isn't permitted to request Majus to swear by anyone other than Allah. That's because all the disbelievers realize that Allah exists and do not deny the fact that this universe has a creator. For instance, Allah said: (If indeed thou ask them who it is that created the heavens and the earth, they would be sure to say, "(Allah) $)^{2}$.

The adherents of Al Maleki school adopted the same opinion. Khalil and Al-Dardir suggest through Al-Sharh Al-Kabeer that the oath related to financial right or any other right must be conjoined with the sentence "Allah whom there is no God but him". That shall apply whether the amount of money is big or small amount- even it's less than 0.25 JDs. That shall apply whether the claimant or the defendant is requested to take the oath. If the one taking the oath is Christian, he may add: "by the one who sent down the bible to Christ. The Jewish may add: by the one who sent down the Torah to Mousa. However, both must add: "Allah whom there is no God but him"3.The adherents of Al-Shafi' school adopted the same opinion. They confirmed that Jewish should swear by Allah who sent down the Torah to Mousa and saved him from drowning. The adherents of Al-Shafi' school suggest that Christians can swear by Allah who sent down the Bible to Christ. The adherents of Al-Shafi' school suggest that Christian, Majusi and idolatries can swear by Allah who created him ${ }^{4}$.

The adherents of Al-Hanbali school believe that one must swear only by Allah. That's because Allah says: "They swear their strongest oaths by Allah, that if a (special) sign came to them, by it they would believe. Say: "Certainly (all) signs are in the power of Allah, but what will make you (Muslims) realise that (even) if (special) signs came, they will not believe"5. Prophet Mohammad (PBUH) asked Rakanah ben Yazidto take an oath about a divorce-related matter. Thus, Rakanah said: (I swear by Allah that I didn't want to divorce my wife". Othman asked Ibn Omar to take an oath through saying: Swear by Allah that you have sold the item which doesn't include any defect. As for the Jewish people, they swear by Allah who sent down Torah to Mousa, parted the sea for him and saved him from Pharon. Abu Hurayrah said that Prophet Mohammad (PBUH) said to several Jewish men: "I ask you to swear by Allah -who sent down Torah to Mousa- with stating that there isn't any punishment in Torah for committing adultery by a married person". The Christian person should swear by Allah who sent down the bible to Christ and gave him the capability to revive the dead and cure the blind and the leper. As for the Majusi, idolatries and Sabian- who worship a god other than Allah- they shall swear by Allah ${ }^{6}$

As for the adherents of other schools, they all believe that the oath must be conjoined pled with the word (Allah). Ibn Hazem Al-Thaheri said that the one must swear by Allah or any of his attributes. He bases his opinion on the following verse: "O ye who believe! When death approaches any of you, (take) witnesses among yourselves when making bequests,- two just men of your own (brotherhood) or others from outside if ye are journeying through the earth, and the chance of death befalls you (thus). If ye doubt (their truth), detain them both after prayer, and let them both swear by Allah: "We wish not in this for any worldly gain, even though the (beneficiary) be our near relation: we shall hide not the evidence before Allah: if we do, then behold! the sin be upon us"7. Thus, Allah didn't request the oath taker to add something else. Ibn Omar states that Prophet Mohammad states: "The one who swears must swear only by Allah" ${ }^{8}$. As for the adherents of Al-Zaydy school, they believe that one must swear only by Allah. Thus, if one is Christian, he shall swear by Allah who sent down the Bible to Christ. If one is Jewish, he shall swear by Allah who sent down Torah to Mousa. If one is Majusi, he shall swear by Allah who created him or fire because he glorifies fire. As foratheists, idolatries, Sabianand Zindiq, they must swear only by Allah. If a non-Muslim swears by Allah who sent down Quran to Mohammad, his oath isn't admissible nor concluded ${ }^{9}$. The oath isn't admissible nor concluded if it includes a reference for a Divine book without a reference to the one who sent it down. In addition, the oath form is considered void if it's vague. For instance, a Majusi person can't swear by (the light), provided that it's one of Allah's attributes. That's because a Majusi person considers the light a God and vagueness shall be associated with the oath form. The same was confirmed by the adherents of Al-Imami school $^{10}$.

In Matn Al-Neel, an adherent of Al-Abadi school states: (The defendant requested to take the oath shall bring the Holy Quran and the ruler shall take it from him. Then, the defendant shall say "I seek refuge in Allah from the cursed Satan" and say the first couple of verses of Al-Tur Surah. Then, the ruler shall say: "Do you swear by Allahwhom there is no God but him, shall take revenge on disbelievers, and capable of hurting and benefitting people, taking the blessings and grace granted to you, and punishing you as the Quran states- that the claimant's claim is

\footnotetext{
${ }^{1}$ Ibn Dawood. About the oath and its associated issues. op cit.

${ }^{2}$ Verse 25. Luqman.

${ }^{3} \mathrm{Ibn}$ Dawood. About the oath and its associated issues. op cit.

${ }^{4}$ Ibn Dawood. About the oath and its associated issues. op cit.

${ }^{5}$ Al-An'am, Verse 109

${ }^{6} \mathrm{Ibn}$ Dawood. About the oath and its associated issues. op cit

${ }^{7}$ Al-Ma'edah. Verse 106

${ }^{8}$ Ibn Dawood. About the oath and its associated issues. op cit.

${ }^{9}$ ibid.

${ }^{10}$ ibid
} 
false. Then, the Holy Quran shall be risen against the defendant's fact in order to kiss it and take the oath with his hand on it) ${ }^{1}$. In modern Islamic jurisprudence, Ibn Baz supported this belief in a Fatwa issued by him. The latter Fatwa indicates that swearing by anyone other than Allah shall not make the oath admissible ${ }^{2}$

In short, the oath isn't concluded nor admissible if one swears by any being other than Allah. That applies to saying: "by my obligation under Allah's legislations", "by the Holy Quran", "by Ka'bah", or "by Allah's prophets". If a person took such an oath, he shall be considered disobeyer for Allah ${ }^{3}$. After shedding a light on the oath form under the Islamic jurisprudence, it is necessary to shed a light on the oath form under status laws through the argument below.

5.3 The Oath form Under the Provisions of the Jordanian Law and the Arab Laws Mentioned in the Present Study: Based on the aforementioned section, it's not permitted to take an oath that is not conjoined with the word "Allah" or any of his attributes. Under all the schools of Islamic jurisprudence, the oath that is not conjoined with the word "Allah" or any of his attributes shall not be considered admissible nor concluded. However, what is it like under the Arab legislation-including the Jordanian legislations. These legislations consider the conclusive oath as a mean of proof that shall settle the dispute through relying on the adversary's conscience when there isn't any proof. The Arab laws mentioned in the present study include the conditions and procedures of taking the oath and the required oath form. There are several requirements that must be met in the conclusive oath to be admissible. These requirements are: the claimant, the oath taker, intention, and oath form ${ }^{4}$. When these requirements are met, the oath shall be admissible legally and having a legal effect. The argument below sheds a light on the form of the oath form under the Arab legislations.

Article 66 of the Jordanian code of proof states "taking the oath is represented in saying: "I swear by Allah" 56 then the oath taker shall say the form determined by the court". All the Arab legislations oblige the oath taker to conjoin his oath with the word "Allah" jurists. Such jurists believe that the oath must be conjoined by the word (Allah) in order for the oath taker to feel the holiness and greatness of Allah. Such feelings shall refrain the oath taker from taking the oath if he's lying. However, if the oath taker isn't saying the truth under the oath, he shall be liable for punishment during life and

\footnotetext{
1 ibid

${ }^{2}$ There's no doubt that polytheism involves swearing by Prophet Mohammad, righteous people, angel, Jin, stars, someone's honor, one's life. That is because Prophet Mohammad (PBUH) states: "The one who wants to take an oath must swear by "Allah" only, otherwise he must refrain from taking the oath". Prophet Mohammad (PBUH) also states: "The one who wants to take an oath mustn't swear by anyone other than Allah". Prophet Mohammad said: "The one who swears by anything other than Allah shall be considered polytheistic". He also said: "The one who swears by anything other than Allah shall be considered a disbeliever". He also said: "The one who swears by trustshall not be considered one of us". He also said: "The one who swears by Al-Lat and Al-Uzzamust say there's no God but Allah". That means that swearing by anyone other than Allah isn't permitted. It is considered something prohibited and shall make one polytheistic. However, it's considered an act of minor polytheism. Thus, Muslims must avoid swearing by anyone other than Allah. Muslims may swear by Allah, or any of his attributes. They aren't permitted to swear by any being other than Allah. Thus, it's prohibited to swear by prophets nor any other being. The one who swears by anyone other than Allah must repent, do good deeds as a sign of repentance and pledge himself to refrain himself from doing so again. Allah sent us prophets to show us truth and clarify it. The last prophet is Prophet Mohammad who told people to swear only by Allah onlysince the beginning of inviting people to Islam and after the Prophet migrated to Al-Madineh. Prophet said: "Don't swear by your fathers, mothers, nor peers. Don't swear by Allah unless you are honest". If one swears by any being other than Allah with believing that this being can control the universe or worths worshiping, it shall considered an act of major polytheism. If one swears by a being other than Allah due to being a verbal habit, or due to loving or glorifying this being without believing that this being can control the universe nor worths worshiping, it shall be considered an act of minor polytheism. In such a case, one must repent and pledge himself to refrain himself from doing so. http://www.binbaz.org.sa/noor/881

${ }^{3}$ Al-Hali, Al-Sara'er

${ }^{4}$ Article 133 of the Yemeni code of proof. It suggests that the oath requirements are: the claimant, the oath taker, intention, and the oath form ${ }^{5}$ Citing from a book titled (Facts about the World) which is issued by the US Central Intelligence Agency (CIA), a statistics issued by the CIA in 2010 states that $31.5 \%$ of the world population are Christians. $23.20 \%$ of the world population are Muslims. $0.23 \%$ of the world population are Jewish. $13.8 \%$ of the world population are Hindu. $6.77 \%$ of the world population are Buddhist. $0.35 \%$ of the world population are Sikhs. $0.11 \%$ of the world population are Baha'is. $10.95 \%$ of the world population are adherents of other religions. $9.66 \%$ of the world population are not religious. 2.01\% of the world population are atheists. Please visit the following website: https://www.cia.gov/library/publications/resources/the-world-factbook/

These percentages are published in a report issued on 2012 by Pew Research Center which is specialized in issues related to religions and people.

${ }^{6}$ Article 66 of the Emirati code of proof in the civil and commercial matters states: "Taking the oath is represented in saying (I swear by Allah; the Almighty). Then, the oath taker must say the form determined by the court. The one requested to take the oath is entitled to take the oath in a manner that's in accordance with provisions of his religion if he requested that". Article 136 of the Yemeni code of proof states: "Taking the oath is represented in saying (I swear by Allah, the Almighty). Then, the oath taker must mention the statement he wants to prove through the oath. The oath may be taken in a written manner. It may be taken through using sign language if the oath taker is dumb and is illiterate". Article 141 of the Palestinian code of proof states: "Taking the oath is represented in saying (I swear by Allah; the Almighty). Then, the oath taker must say the form determined by the court. The one requested to take the oath is entitled to take the oath in a manner that's in accordance with provisions of his religion if he requested that". Article 70 of the Syrian code of proof in the civil and commercial matters states: "Taking the oath is represented in saying (I swear by Allah). Then, the oath taker must say the form determined by the court. The one requested to take the oath is entitled to take the oath in a manner that's in accordance with provisions of his religion if he requested that".

${ }^{7}$ The most popular religions in the world include: Islam, Christianity, and Judaism. The adherents of each one of those believe that there is no God other than Allah. As for the adherents of any other religion, they don't believe so. So, they have different beliefs.
} 
after life. Ibn Baz issued a fatwa when he was asked about swearing by Al-Lat and Al-Uzza. That latter Fatwa implies that Al-Nesa'i narrated Hadith Sahih. This Hadith implies that Sa'd Iben Abi Waqqas swore by Al-Lat and Al-Uzza. Thus, he asked Prophet Mohammad whether such an oath is concluded or not. So, the Prophet said: \{Say (There is no being worth worshipping except for Allah, alone, who has no partner. For Him is the Dominion and to Him is the praise. In His hand is all good and He has power over all thing).Then, spit out three time on your left wide. Then say "I seek refuge in Allah from the cursed Satan" and do not do that again $\}$. This Hadith confirms that it's prohibited in Islam to swear by any being other than Allah. It also indicates that it's an act of polytheism to swear by any being other than Allah. It also indicates that Prophet Mohammad ordered such an oath take to refrain from doing that again ${ }^{1}$

Article (2) of the Jordanian Constitution states that "Islam is the religion of the State and Arabic is its official language". Article 2 of the Jordanian civil code states that "1-The articles of the present law shall be applicable to the issues they address through relying on the words and their meanings. No one is entitled to interpret any article of the present law at his own discretion. 2-If the court didn't find any article in the present law to base its judgment on, it can base its judgment on the provisions of Islamic jurisprudence that are consistent the most with the provisions of the present law. In case the court didn't find such provisions, it can base its judgment on the provisions of Shariah....". Else; the Article 3 of the Jordanian civil code states that: (Understanding, interpreting, explaining and identifying the implicit meanings of the articles of the present law must be based on the rules of the Islamic jurisprudence). That means that all the articles of the latter law must be enforced by a judge and no judgment can be made at the judge's own discretion. If the article is vague, the judge must interpret it based on the rules of Islamic jurisprudence rather than his own personal view. Thus, if a lawsuit party requested his adversary to take the conclusive oath and the adversary accepted that, the court must request him to take an oath conjoined with the word (Allah). The court must make the adversary take the oath in accordance with article 66 of the Jordanian code of proof. Thus, Christians, Jewish, and Muslims must take an oath conjoined with the word Allah. However, the Jordanian law didn't shed a light on the oath takers who are not Christian, Jewish, nor Muslim (i.e. Non-Ketabi). For instance, the oath taker may be a person who isn't believes that there is no God other than Allah. Thus, in such a case, the judge must interpret the articles of the law based on the rules of Islamic jurisprudence in terms of the admissibility of the oath taken by a non-Ketabi person based on his own beliefs.

When analyzing article 2 of the Jordanian constitution and articles (2) and (3) of the Jordanian civil law, it can be understood that a judge must take these articles into consideration when determining the form of the oath that a non-ketabi person shall take. These articles are binding and no judge is entitled to violate them. Thus, a Jordanian judge must refuse having a person swearing by any being other than Allah. According to article 138 of the Syrian code of procedures: "The oath taker must take the oath based on the intention of the one requesting the oath rather than his own intention". The judge must reject the oath that isn't conjoined by the word "Allah" or the God who created the thing that the oath taker worships. For instance, if the oath taker worships fire, he must take an oath conjoined by the God who created fire. If the judge did something other than that, he shall be considered violating article 2 of the Jordanian constitution. Under the latter article, Islam is official religion of the state. Thus, the Jordanian legislator doesn't recognise any other religion other than Christianity and Judaism. The adherents of these religions believe that there is no God other than Allah. Thus, Christians, Jewish and Muslims must swear by Allah, otherwise their oath shall not be considered admissible.

When reviewing the explanatory memorandum of the Jordanian civil code, it can be noticed that articles 2 and 3 clarified the meaning of (the rules of Islamic jurisprudence). The review of these articles states: (If there isn't any article in law, the judge must base his judgment on the provisions of Islamic jurisprudence. That applies regardless of the Islamic jurisprudence school that the judge shall base his judgment on. The judge shall select the provision that is considered the most consistent one with the articles of the law. If the judge didn't find a provision, the judge shall search for the relevant Shariah principles to base his judgment on. That is because the Jordanian legislator relied on the Code of the Ottoman Empire and Islamic jurisprudence. When the Jordanian legislator didn't find a relevant provision in those two sources, he relied on the provisions derived from the general rules). Through the third page of the explanatory memorandum written by Mohammad Zaki Abd elber; a legal expert, article 2 and 3 were analyzed. Quoting from the latter page,(The project started by clarifying the official or binding sources that the judge must rely on to elicit the legal rules that he must base his judgment on. Such sources include the provisions of Islamic jurisprudence followed by the principles of Shariah. The legislator differentiated between the meaning of provisions of Islamic jurisprudence and the principles of Shariah. For instance, such provisions are documented in the books of Islamic jurisprudence, whereas these principles are derived from the Holy Quran and Sunah). Dr. Mohammad Zaki states that "The legislator didn't rely on Al-Hanafi school of Islamic jurisprudence only. In fact, he relied on all the schools of Islamic jurisprudence. He also relied on the opinions of jurists. Thus, there are several approaches that the judge may adopt to issue a judgment. However, he must base his judgment

\footnotetext{
Iben

$\mathrm{Baz}$ 
on the jurist opinion or the Islamic jurisprudence provision that's considered in agreement the most with Shariah. That should be done through maintaining the unity and consistency of the articles of the law, or taking into consideration the things that are consistent the most with the requirements of the age".

Thus, it can be concluded that Islamic jurisprudence has a major impact on the judge's decision when interpreting and explaining the vagueness of legal texts. It can be concluded that when a judge explain such vagueness, he must review the opinions of Islamic jurists of various schools of Islamic jurisprudence. Thus, he shouldn't provide an opinion based on one Islamic jurisprudence school -e.g. Al-Hanafi school only- without taking the other schools into consideration. It was also concluded that the adherents of each school of Islamic jurisprudence agree that the oath that is not conjoined with the word (Allah) isn't admissible. The same is confirmed by article 152 of the Yemeni code of proof No. 21 of 1992.The latter article states: "The non-Muslim person who shall take the oath may take the oath in a manner that's in accordance with provisions of his religion, provided that this manner is consistent with the monotheistic belief'. That confirms that the oath taker must take the oath conjoined with the word (Allah) or any of his attributes regardless of the oath taker's religion.

Debatable issues shall arise when shedding a light on the oath taken in a way that's not consistent with monotheist belief. Such issues shall arise when requesting to enforce a judgment issued by a foreign country's judiciary in an Arab or Muslim country. For example, a judgment may be issued by a Jordanian court based on a conclusive oath taken by a non-Ketabi adversary. If the wining lawsuit party wants to enforce the judgment in the Republic of Yemen, the Yemeni judiciary shall reject enforcing the judgment. That's because the oath was made in a manner that is not consistent with the monotheist belief displayed in article 152 of the Yemeni code of proof. In such a case, a Yemeni court may refuse the enforcement of the judgment based on articles $(30$ ، 36 ، 37) of Riyadh Arab Agreement for Judicial Cooperation ${ }^{1}$. These articles entitled a country's judiciary to refuse implementing the judgments ofcourts and arbitrators, if these judgments are not in conformity with the provisions of Shariah, or constitution, public order or morals of the country requested to implement the judgment.

\section{Conclusion and Recommendations:}

Legislators aimed to establish a litigation system through laws in order to protect people's rights. Such a system usually requires one to provide a proof indicating the defendant is acquitted. The proof system is a very significant system because it protects people's right and ensures the establishment of stability. Therefore, legislators enacted substantive and procedural rules to make the proof system effective. Legislators aim to ensure that these rules are clear for the disputed parties and courts.

Oath- specifically the conclusive oath- is a mean of proof that is included in the codes of proof. When the lawsuit party doesn't have a proof, he shall request his adversary to take the oath in order to settle the dispute. In such a case, the lawsuit party shall rely on his adversary's conscience. However, the oath is a significant mean of proof. That's because the judgment made based on such an oath shall settle the dispute. It shall be considered a final judgment and no appeal can be filed against it provided that the procedures of taking and requesting the oath are in conformity with the provisions of the law.

The researcher found that the oath shall be considered legally admissible if it's conjoined with the word (Allah). That's confirmed by article 66 of the Jordanian code of proof. For instance, that latter article states: "Taking the oath is represented in saying (I swear by Allah). Then, the oath taker must say the form determined by the court". Through the present study, the researcher aimed to answer several questions; if one swears by any being other than Allah before a Jordanian judge, would his oath be admissible? If the Jordanian judge requested a lawsuit party to take an oath that's not conjoined by the word (Allah), is the judge violating the state's public order? In such a case, is the judge violating the provisions of the Jordanian constitution? What's the oath form that must be said by the non-Ketabi person?

Several results were reached through the present study. First, it was found that the adherents of each school of Islamic jurisprudence and the codes of proof agree that the conclusive oath can't be requested unless the

\footnotetext{
${ }^{1}$ Article 30 of the Riyadh Arab Agreement for Judicial Cooperation states: (The judgement shall not be recognized in any of the following cases: A-If the judgment violates any of the provisions of Shariah, or constitution, public order or morals of the contract party requested to recognize the judgment).

Article 36 of the Riyadh Arab Agreement for Judicial Cooperation states: (The contract party - that the writs of execution are signed at his landis obliged to ensure their execution by the other contract parties. That should be done in accordance with the procedures that govern court judgments if the procedures apply to writs. The execution of these writs mustn't violate the provisions of Shariah, or constitution, public order or morals of the contract party requested to execute the judgment).

Article 37 of the Riyadh Arab Agreement for Judicial Cooperation states: (No violation may be committed against articles 28 and 30 . Along with that, the contract party requested to execute the judgment must recognize the judgments made by arbitrators. These judgments must be executed by any other contract party in the same manner mentioned in this chapter. However, the legal rules of the contract party requested to execute the judgment must be taken into consideration. The judiciary of the contract party requested to execute the judgment isn't entitled to look into the subject of dispute that was subjected to arbitration. It's not entitled to reject the execution of the judgment. That shall apply except in the following cases:

E-If the judgment of the arbitrators violates the provisions of Shariah, or constitution, public order or morals of the contract party requested to execute the judgment)
} 
claimant isn't capable to provide a proof to support his claim. Second, it was found that the court isn't entitled to practice the authority of the claimant through requesting the defendant to take the conclusive oath at its own. If the court did so, an appeal can be filed against the judgment made based on such an oath. The claimant is the only one entitled to request his adversary to take the oath. Third, the adherents of each school of Islamic jurisprudence agree that the oath that is conjoined by any being other than Allah isn't admissible. That applies to saying: "by my obligation under Allah's legislations", "by the Holy Quran”, "by Ka'bah", or "by Allah's prophets". If a person took such an oath, he shall be considered disobeyer for Allah. Fourth, under the Arab laws -including the Jordanian laws- the one taking the oath must say (I swear by Allah). Then, the oath taker must say the form determined by the court. Fifth, most of the Arab legislators- including the Jordanian legislator- didn't enact legislations that deal with the oath taken by a non-ketabi person. Sixth, article152 of the Yemeni code of proof No. 21 of 1992 . The latter article states: "The non-Muslim person who shall take the oath may take the oath in a manner that's in accordance with provisions of his religion, provided that this manner is consistent with the monotheistic belief". That confirms that the oath that's not conjoined by the word (Allah) isn't admissible. Seventh, if there's a matter that's not tackled by the Jordanian code of proof, the judge must refer to the Jordanian civil code. That applies to the oath form. Eighth, under article 2 of the Jordanian civil code, if there's a legal matter that's not tackled by the Jordanian civil law, Islamic jurisprudence and Shariah are the references to be sought. Under article 2 of the Jordanian constitution, article 66 of the Jordanian code of proof, and article 2 of the Jordanian civil law, the oath form must be consistent with the monotheistic belief. That confirms that the oath taker must take the oath conjoined with the word (Allah) regardless of his religion. Otherwise, the oath shall be inadmissible and violating the Jordanian public order.

Based on the aforementioned, the researcher offers the Jordanian legislator three options. It's inconceivable to see the Jordanian legislator adopting the first option. The first option is represented in eliminating the oath as a mean of proof and recognizing only the other means of proof mentioned in the law. Such an option is based on the belief that the claimant committed acts of negligence against himself. Thus, if the claimant couldn't provide a proof, he shall lose the lawsuit. The second option is represented in keeping the oath as a mean of proof with eliminating article 66 of the Jordanian code of proof. Thus, the legislator would allow the adversary to take the oath without being conjoined with the word (Allah). If the judge did so, he would be violating article 2 of the Jordanian constitution and article 2 of the Jordanian civil law. The judge shall be considered violating these articles, unless the legislator eliminated these articles. However, it is not likely to see the legislator eliminating these articles. The third option is represented in keeping article 66 of the Jordanian code of proof with obliging judges to request the oath takers to take the oath conjoined with the word (Allah). However, the legislator can't ensure the compliance of all judges with that. In the light of the aforementioned, the researcher recommends adjusting the law to have an article stating the following: (Taking the oath is represented in saying (I swear by Allah). Then, the oath taker must say the form determined by the court. The court is entitled to make the oath takers take the oath in a manner that's in accordance with provisions of their religion, provided that this manner is consistent with the monotheistic belief).

\section{References:}

\section{References Written in Arabic:}

Ibrahim, Ahmad Baik, and Ibrahim, Wasel Ala' Al-Deen. The legitimate means of proof under Shariah with identifying the differences between the schools of Islamic jurisprudence and the types of proofs and achieving a balance between them. The fourth edition. Al-Azhareye Le Turath. 2003.

Ibn Saleh, Sarah.The authority of the civil judge in assessing proofs: A study under the civil law and the civil and administrative procedures law. MA thesis. University of Skikda.Skikda. Algeria. 2012.

- Abu Al-Wafa, Ahmad. The rules of proof in the civil and commercial matters. Al-Wafa publishing and distribution house. Alexandria. 2015.

- Al-Bayhaqi, Abu Baker. Al-Sunan Al-Kubrah. Reviewed by Mohammad Abed Al-QaderAttah. Part No.10. First edition. Al-Kotob Al-Elmeya publishing and distribution house. Beirut.1994.

- Al-Jarjani. Ali ben Mohammad. The Definitions. Al-Kotob Al-Elmeya publishing and distribution house Beirut. 1983.

Al-hali, Ibn Edres. Al-Sara'er. Al-Nasher Al-Islami publishing and distribution house. 1410 AH.

- Al-Hanafi, Ibn Hamam; Zadah, Qadi; Al-Baberty, Akmal and Jalbi, Sa'di. Explanation of Fath Al-Qadeer with its supplement: Explanation of the fruits of thoughts, the priority of care over Guidance and Sa'adiJalbi's thoughts in this regard. Al-Amereye publishing and distribution house. Cairo. 1315.

- Al-Rjoub, Saleem Contradiction and Weighting in the means of proof. A comparative legal jurisprudential study. PhD dissertation. The University of Jordan. Amman. 2006.

- Al-Zuhaily, Mohammad. Means of proof under Shariah in relation to civil paper works and personal status. First part. Al-Mu'ayad bookshop. Kuwait. 1994.

- Al-Zu'bi,Awad. Al-Wajeez about the Jordanian civil procedure code. First edition. Wa'elpublishing and 
distribution house. Amman. 2007.

- Al-Sa'di. Mohammad. Al-Wadeh for the illustration of the civil code - Proving in the civil and commercial matters. Al-Huddapublishing and distribution house. Algeria. 2009.

- Al-Sanhury. Abed Al-Razeq. Al-Waseet for Illustration of the civil code: An overview about the theory of commitment-proving- the implications of commitment- Al-Halabi publication about rights-related issues. Beirut. 2009.

- Al-U'budy, Abbas. Illustration of the civil code of proof. $1^{\text {st }}$ edition. Al-Thaqafe publishing and distribution house. Amman. 2011.

- Al-Kilany. Mahmoud. The rules of proof and the execution-related provisions. $1^{\text {st }}$ edition. Al-Thaqafe publishing and distribution house. Amman. 2013.

- $\quad$ Baker, IsmatAbed Al-Maeed. Illustration of the code of proof. Al-Sanhuri house for publishing in the field of law and political sciences. Baghdad. 2018.

- Bakhush, Yahya. Means of proof under the Algerian civil code and Islamic jurisprudence. The National Institution for Publishing Books. Algeria. 1981.

- Shandi, The provisions of exceptional cases in relation to the oath under Shariah (A comparative jurisprudential study). Al-Najah Journal for the Studies in the field of Human Science. Al-Najah University.Vol.20. Issue. 1. 2005.p.109-132.

- Othman, Mohammad Ra'fat. The judicial system under the Islamic jurisprudence. The second edition. AlBayan publishing and distribution house. Cairo. 1994.

- Qasem. Mohammad Hassan. The code of proof in the civil and commercial matters. Al-Halabi publication about rights-related issues. Beirut. 2005.

- Kala'ji. Mohammad. Dictionary of the language of jurists. Al-Nafa'es publishing and distribution house. 1988.

- The Castle of je, Mohammad Al-Rawas. Al-Moyasarah Encyclopedia of jurisprudence. $1^{\text {st }}$ edition. AlNafa'espublishing and distribution house. Beirut. 2000.

- Nash'at. A letter about proof. Part No. 1. First edition. Al-Elem LelJamee' publishing and distribution house. Beirut. 2005.

\section{References written in English language:}

- Ibrahim, O. 1986. Proof in Islamic Law with Special Reference to the Sudan. PhD dissertation. The University of London. London. 